\title{
HABITUAL INTERACTION ESTRANGED
}

\section{NOEL PACKARD}

\begin{abstract}
:
Marx's alienation, dialectical materialism and stratification theory, provides a lens through which to explore an explosion of statistical studies regarding on-line interaction and possible Internet addiction (IA). Acclaimed authors Turkle, Greenwald and Foer, warn that consumer interaction in the digital world has risks that can be countered by individual responsibility and action. Their claims are juxtaposed to what ordinary, individual, cell phone and social media users self-report en masse about their on-line experience, documented in thousands of statistical and empirical studies. Marx's Economic and Philosophic Manuscripts of 1844 and Marx's Theory of Alienation by Mészáros are used to explore what alienation looks like in a perpetuum mobile world. The analysis melds Marx's alienation theory to findings, presenting a Marx inspired system of interactive appropriation and alienation. Regardless of how Internet users experience social media; or differing interpretations of addiction; or how researchers study internet usage; one undisputable fact emerges: this electronically mediated mode of production appropriates wealth from Internet users to enrich what appears to be a $1 \%$ class of telecommunication industry owners. Other conclusions are: Marx's theories apply in a non-Machine epoch context, in which: the intangible electronic memory volunteered by telecommunication customers, who may risk Internet addiction (IA), is a free by-product of a system of appropriation exchanged for alienation, which is in a transitional mode, representing potential future surplus value. Given this, IA might help increase telecommunication industry profits, government contracts, money hoarding and turn over. The presuppositions of the paper are: 1) on-line communication is, according to statistics, normal, pervasive and potentially addictive; 2 ) statistical studies are a scientific cornerstone of sociological research; 3) studies discussed may, or may not, honestly represent what ordinary users of social media report; 4) Marx's theories and methods are part of sociology's cannon and 5) Internet addiction (IA) is considered a global problem, although it lacks official medical etiology and researchers across disciplines (communication, psychology, medicine, to name a few) disagree about what causes it.
\end{abstract}

\section{Keywords:}

alienation, Marx, Internet Addiction (IA), social media, telecommunication, cell phone, AI

JEL Classification: Z13, L96, D12

\section{Authors:}

NOEL PACKARD, Victoria University of Wellington, New Zealand, New Zealand, Email: packarnoel@myvuw.ac.nz

\section{Citation:}

NOEL PACKARD (2018). Habitual Interaction Estranged. International Journal of Social Sciences, Vol. VII(1), pp. 69-94., 10.20472/SS.2018.7.1.005 


\section{Introduction}

In the German Ideology (1894) Karl Marx wrote: "The class which has the means of material production at its disposal, has control at the same time over the means of mental production, so that thereby, generally speaking, the ideas of those who lack the means of mental production are subject to it." (1978 p. 172) Today Marx's ideas about the production of consciousness apply to the history of information literature, which tends to center on recognizable names like I.B.M., Gates, or GAFA (Google, Apple, Facebook and Amazon). Ordinary people who helped build the digital world are less well known (Haigh, 2010, p. 18 fn. 2) with Egger's The Circle (2013) providing a fictionalized, bestselling, exception. Here we consider what some experts write about risks in the digital age and then look at what ordinary people have self-reported in surveys (and appear corroborated in empirical studies) regarding their interactions with social media and their concerns about it. Marx's alienation and class theories, posited in the Machine Age, are applied, to test its relevance in a new electronic mode of production era scenario.

Sherry Turkle, Glenn Greenwald and Franklin Foer are acclaimed authors who write about how the digital age is changing our emotional lives, privacy and ability to exercise free will, democratic government and thought. All three write from a professional position of moving among those close to the GAFA epicenter. Turkle is the Abby Rockefeller Mauzé Professor in the Science, Technology and Society program at MIT. She has a joint doctorate in sociology and psychology from Harvard University. As an ethnographer Turkle first studied the pioneers of artificial intelligence (AI), to author her famous The Second Self: Computers and the Human Spirit, now in its' $20^{\text {th }}$ edition. In a vast array of publications Turkle writes eloquently and expansively about a range of people, from scientists to children and about their relationships with interactive objects. Her Alone Together: Why We Expect More From Technology and Less from Each Other (2011) takes a critical sociological and psychological look at how the internet mediated world impacts human relations, or inversely how "our technology" shapes us (Turkle, 2011, p.19). She describes how electronically interactive devices enable humans to infuse objects with their human emotional needs. She raises issues in a multidimensional way about human labor being displaced by machines and about the diminishment of ethics, sense of identity, solidarity, solitude, selfreflection and essentially of human love and friendship - displaced by surrogate machine mediated intermediaries. At the end of the book Turkle describes a funeral service where attendees are texting during the service and concludes, without much discussion about the possibility of all out human addiction to social media, that only we can check our habits with interactive devices (Lipman, 2013; Turkle 2011, p. 296). Turkle edited a book of essays about children and objects titled Falling for Science: Objects in Mind. In the introduction she writes, "Objects provide encounters with transparent systems and manipulable microworlds. They provide opportunities to develop intimacy with objects" and writes that 
objects are a path "into scientific creativity" (Turkle, 2008, p. 12-13), but not (possibly) to addiction. She writes a lot about interactive devices as robots and notes that as robotics learn to love and care for humans, they will also learn to expect love from humans in return. In 2015, Turkle wrote, Reclaiming Conversation: The Power of Talk in the Digital Age, which advocates for face-to-face conversation. Turkle strives to theoretically and politically negotiate the divide between a digital and a non-digital world; her abundant and important work captures important moments in this new-world development, reflecting the contradictions manifest in both worlds, as one feeds into the next.

In 2014 Glenn Greenwald's book, No Place to Hide: Edward Snowden and the NSA, and the U.S. Surveillance State unpacked disturbing sociological aspects of the U.S. surveillance state, while warning US citizens they are now "witting" targets of government spying. These revelations were from the whistleblowing efforts of Edwin Snowden a former National Security Agency contract employee turned whistleblower. Like Turkle, Greenwald has concerns about Internet use and abuse, but in a different realm of the electronic landscape. Greenwald's book reports on government spying on Internet users. Greenwald is an expert legal analyst regarding surveillance state politics and the co-founder of an electronically mediated multi-platform company, The Intercept, which is supportive of whistleblower investigative journalism. Greenwald is a former U.S. constitutional lawyer and recipient of: a 2013 investigative journalism award from the Online News Association; the Esso Award for Excellence in Reporting; the 2013 Pioneer Award from the Electronic Frontier Foundation; and the 2013 George Polk Award for National Security Reporting; and was named by Foreign Policy as one of the top 100 Global Thinkers. Like Turkle, Greenwald concludes that it is up to the individual, like Edwin Snowden, to check behavior and stand up for justice. The individual who has the will, can go without electronic devices or adopt better encryption and alternative NSA unfriendly browsing tools - to lead the way in counterbalancing the power of the robot, the machine, the surveillance state and the governmental and corporate power behind it (Greenwald, 2014, pp. 252-253; Packard 2017).

In 2017, Franklin Foer, former editor of the New Republic and a correspondent for The Atlantic authored World Without Mind: The Existential Threat of Big Tech; a book about famous personalities who helped shape the Silicon Valley phenomena (including some he worked for), along with his own reflections and concerns about the tech companies absorbing "the totality of human existence into their corporate fold."(p. 228) Foer spent considerable time working close to or with tech companies but unlike Greenwald and Turkle, Foer writes more like an ex-tech industry insider, turned whistleblower. Foer explains in traditional beat journalism style, the history of the development of the important components of the computer age, describing the people who helped developed those components. He puts a human face upon the digital products we use. He describes many 
legendary people who helped pave the way for Silicon Valley for example, Stewart Brand (Whole Earth Access), Bill Gates (Microsoft), Linus Torvald (Linux) Peter Thiel (Pay Pal) and even Sherry Turkle, whose work he comments about in this way: "She compared Al, with its theory about the programmable mind, to psychoanalysis and Marxism - as 'a new way of understanding almost anything."' (Foer 2017, p. 36). And "almost" is a good qualifier, since there is yet to be an officially declared "Manifesto" against Al, Internet use, robots or cellphone radiation, among many other electronic modes of production things. But perhaps a Manifesto in favor of those things is being alluded to in Foer's cryptic citation of a longer Turkle quote $(2017$ pp. 36, 237, n36) that leads the reader to pages in different editions of the Second Self with titles such as, "The New Philosophers of Artificial Intelligence: A Culture with Global Aspirations" (Turkle, 1984, p. 247) and "Thinking of Yourself as a Machine" (Turkle, 2005, p.247).

Foer also describes historical engineers who helped pave the way for the computer such, as Leibniz, Desecrate and Turing. He unpacks the historical alliance of Western Union and the Associated Press, which influenced US government elections, terminated federal efforts to install racial equality programs into the US south and installed a President who opposed regulating or nationalizing Western Union's telegraph network (Foer 2017, pp.111-117). Foer compares abuse of power by telecommunications companies of the past, to abuses of power by contemporary GAFA companies and emphasizes how the digital technology enhances secrecy and privacy for the companies; key ingredients that allow any kind of abuse to continue by protecting abusers' anonymity, while the ordinary user of on-line services risks the opposite - exposure and exploitation of his/her data, which "provides an X-ray of the soul" (pp. 200-201). Foer argues that the GAFA companies have eroded the integrity of institutions that provide intellectual materials that make critical thinking, contemplation and decision-making in an informed Democracy possible. Foer argues that tech companies are under-regulated, un-concerned about social media users' privacy and very preoccupied with building an "unabridged database of global knowledge" that trains algorithms to track patterns, discern images, understand language and ultimately improve upon the human brain or at least outsource it (Foer, 2017, pp. 8, 33, 38, 55, 72). Foer reminds us that outsourced thinking is really outsourced thinking to the corporations that both run the machines and dictate patterns of work and behavior (2017, p.132). Outsourced thinking is prone to a blurring of fact and fiction (2017, p. 151) and is prone to development of what H.G. Wells called the "World Brain" or what Wired editor Kevin Kelly terms the "hive mind" (pp. 27, 178). It might also make the user prone to addiction or hypnotic or "nudging" suggestions, that mediate behavior and reduce the need to independently contemplate choice or think about decisions; it might foster nihilistic thinking, which makes belief in any concept of truth questionable; it is the surrender of the free will to algorithms, that make choices for us, with our consent (p. 229) and it is the reduction of 
our ability to think critically and apart from the electronic corporate infrastructure/landscape, that engulfs our ways of living in the world.

Turkle, Greenwald and Foer argue the individual needs to take responsibility for protecting emotional boundaries, privacy and the ability to make decisions independently and free of algorithmic, artificially intelligent and programed interference. The authors write little or nothing about organized social action to protect society from data tampering and theft, such as class-action lawsuits, boycotts, strikes or organized social movements to demand industry regulation or compensation for secreted telecom and commerce abuses. Turkle advocates individuals check their on-line habits and engage in face-to-face conversation, Greenwald advocates for individual whistleblowing or individual Internet protective measures or abstinence. Foer advocates for a Data Protection Authority to protect citizens' privacy, so companies can't sell our data as an intangible, commodity, in hidden markets that ordinary internet users have little or no access to, or knowledge of (2017, pp. 200-201). He ventures, "Only government policy can really dent the monopolies that increasingly control the world of ideas." (p. 229). Foer is an advocate for reading on paper, an activity he claims tech companies consider "an engineering challenge waiting to be solved." ( $p$. 228). Foer argues for government regulation of telecom companies, government protection of citizens' data and for individuals to return to reading "fixed" printed material, to counter surrendering our free will and our ability to choose, to algorithms.

Such is the assessment of some expert authors who are helping produce the consciousness of a brave new age. But what assessment can be drawn from ordinary social media users who are not acclaimed authors? What do the individuals whom these authors address their warnings toward, have to say about their experience in an electronically mediated world? While social scientists and media experts dispute the theoretical and political aspects of a mediated society, thousands of ordinary people are self-reporting in survey and statistical studies about how much they use and like electronic devices and what worries them about it - like experiencing so-called social media addiction, Fear of Missing Out (FOMO) or problematic cell phone use (PCPU) (Lopez-Fernandez, 2017 , p. 169). Growing numbers of Internet or social media user surveys provide inroads for exploring answers to the question, "How can Marx's alienation and dialectical materialism theory be used to interpret this electronically mediated epoch, with its' social stratification of data collectors on the one hand and on the other hand, data providers, who report concerns about how their on-line activity may possibly be problematic or addictive?"

Statista: The Statistics Portal confirms cell phones are the most used technology in human history with over 2.08 billion users worldwide in 2016, (Lopez-Fernandez, 2017, p. 169). The Portal's "Number of Social media users worldwide from 2010 to 2021" reports that in 2019 it is estimated there will be 2.77 billion social media users around the world, up from 
2.46 billion in 2017 (Staistica.com). The International Telecommunication Union (ITU) is the United Nations specialized agency for information and communication technologies. ITU's many publications monitor an array of worldwide electronic related subject matter and related statistics. It's 2017 ITU Information and Communication Technology (ICT) Facts and Figures publication reports that 70\% of the world's youth (age 15-24) are using the Internet (Sanou, 2017). Statistical studies report people using phones in productive and satisfying ways (Horrigan, 2006) and sometimes in ways that are problematic (Kuss, Griffiths, Karila and Billieux, 2014; Longstreet and Brooks, 2017). The Global Critical Media Literacy Project describes the overall picture this way:

Social media is becoming increasingly popular among all generations. Today, eighty percent of companies use social media to recruit potential employees. One in eight couples today meet on social media. According to studies done by Edison Research, while only twenty-one percent of U.S. Citizens used social media in 2008, today eighty-one percent of U.S. Citizens use social media. Approximately seventy-five percent of Facebook users and fifty percent of Instagram users visit these platforms more than once a day. When we receive positive reinforcement on social media such as getting a "like", dopamine is released in the brain. According to a study done by the National Institute of Health Internet Addiction Disorder cause neurological, physiological, and social issues. Researchers at University of Albany found similarities in the brains of excessive Internet and social media users and the brains of people with substance addictions. Harvard researchers conducted a study investigating why Facebook is so addictive and how it affects the brain. This addiction can be tied to another body of research, which looks at how our brains seek acceptance and approval (Williams and Gaehde, 2017).

A fast growing body of statistical and empirical science seems to be substantiating that human to electronic monitoring device interaction can be consuming, or as researchers currently label it, "Problematic Mobile Phone Use" (PMPU). The World Health Organization considers excessive smartphone use a public health problem (Lopez-Fernandez et al, 2017, p. 169). An article by Larry Dossey, M.D. provides a digest of problematic on-line behaviors, such as: Fear of Missing Out (FOMO); youths in Korea dying from playing internet games for days on end; brain damage from game playing or so-called digital dementia; a Kaiser Family Foundation study finding young children spend more than 7 hours a day on line; texting while driving causes more deaths than drunk driving and about two million, or more, people in the U.S. are injured each year due to distracted walking (texting while walking) (Dossey, 2014). This compiling research is debatable, however, because many of these new disorders are not medically diagnosis-able as addictions; one reporter even writes FOMO is a man-made disease (Gaughan, 2015, p. 2). Researchers 
across the world and across a wide array of disciplines, from medicine to communication, to psychiatry, seem to agree that Internet abuse is problematic but disagree over whether or not addiction can be caused by devices that are outside the body or whether or not what appears to be addiction is really behavior disorder or impulse disorder, enabled by electronic mediation (Huang, 2014, pp. 19-20)

And the debates continue into the realm of how to mitigate or control Internet abuse behavior. For example, researchers in the U.S. dispute whether these disorders or addictions, fit the criteria that would include them into the Diagnostic and Statistical Manual of Mental Disorders (DSM of the American Psychiatric Association), with some Western researchers advocating that internet addiction be taken seriously as a treatable illness (Kuss, 2015) while researchers in China tend to see treatment for the problem as a parental and social control issue (Huang, 2014). Lopez-Fernandez et al. report that studies from Eastern continents suggest phones are a socialization tool that become abused with excessive use, which appears to be an addiction, while other theories consider "identity development" as a reason for abuse (2017, p. 170). Meanwhile "Internet gaming disorder" has been introduced into Section 3 of the DSM-5 as a condition warranting more clinical research (Khazaal et al. 2016).

And there is the issue of liability lurking in the background. Obviously corporations shun responsibility for peoples' on-line behavior as much as they shun any sense of corporate responsibility for the pollution that has helped bring on climate change. Climate change related lawsuits against oil and gas corporations have no doubt put tech companies on alert to protect themselves from liability for any radiation or addiction related health problems their products might cause or enable; which may or may not be a contributing reason to the massive amount and confounding scale, of all these on-going and contested debates. Notably none of the research appears to advocate for government control or regulation of the Internet or social media, as a potential mitigation to this globally recognized growing public health concern.

Whether the science behind this growing jungle of research is accurate and legitimate is for most of us, unknown. Whether the people who self-report about PMPU have clinical or files that document they have a mental illness, is for most of us, unknown. Since there is limited medical etiology regarding electronic-monitoring-device-use the science of this socially experienced Internet abuse problem is still evolving (Lopez-Fernandez et al, 2017, p. 169). Whether telecommunications corporations have vested future interests in helping to develop on-line cures (for customers' on-line behavior problems) or on-line policing actions (to control customers' abusive or habitual media activity) is a good question. Whether or not the huge amount of survey and other research is funded by, or is of market research or liability concern, to the telecom industry, is a good question. What is known 
however, by most accounts, is that electronic media and cell phone use is increasing (Haythornthwaite and Kendell, 2010) an people are acknowledging, through abundant survey and empirical research, that they have attachments to their radioactive, electronic, private phones, which are habitual for some people and possibly problematic, unhealthy or dangerous, for themselves and others. The abundant survey and statistical research regarding Internet and electronic device usage suggests that researchers studying social media usage are, like Turkle and Greenwald, stakeholders in the electronic-medialandscape-economic-enterprise or epoch (Shklovski, Kiesler and Kraut, 2006).

One undeniable and undisputable fact that emerges from all of this, is that a handful of the richest people in the world derive their wealth from telecommunication related industries (Egan and Fiegerman 2017; Elliott, 2017) such as Bill Gates, Carlos Slim Helu, Jeff Bezos, Mark Zuckerman, Larry Ellison, and Warren Buffet. The owner of Amazon.com, Jeff Bezos, is famous for having bought his own rocket company, Blue Origin, The Washington Post and recently bought one of the last food chains in the U.S., Whole Foods, setting off public concerns about food becoming an on-line only commodity (Lovera, 2017). The relationship between people and their cell phone habits and the wealth of six of the richest people in the world, inspires this application of Marxian alienation and class theory, to survey research about our electronically mediated, highly economically divided society, that possibly generates social media use addiction. The following section describes the paper methodology, setting context and providing an overview of Marx's alienation theory, as discussed in Marx's Theory of Alienation (1970) by István Mészáros. The next section discusses survey and empirical research pertaining to habitual cell phone and social media interaction. Marx's alienation theory is revisited and applied to the findings, followed with analysis and conclusions.

\section{Methodology}

It appears electronic monitoring device or cell phone abuse is a growing social fact that people self-report about, yet, the science to explain it is still under-developed or at least un-conclusive (Kuss, Griffiths, Karila and Billieux, 2014). Nevertheless people are using electronic monitoring devices more and more and self-reporting that the interactive experience can both enhance life and also be socially problematic (Williams and Gaehde, 2017). Given this scenario can Marx's theory or method provide sociological insights to this situation? Here Marx's alienation theory and his idea of the "perpetuum mobile" (Marx, 1973 p. 766; 1976, p. 227) are applied to habitual cell phone behavior situated within contemporary dataveillance society. As Brian Roper points out in his book The History of Democracy: A Marxist Interpretation communication is one of the most elementary and important aspects of human existence: 
But in capitalist society all of the major forms of communication are provided and controlled by large corporations and/or governments: telecommunications, mail, electronic and printed media, computers, email and the internet, film, music, advertising, book publishing and so forth. So we are alienated from exercising effective control over the major means, apart from direct face-to-face speech, by which we communicate with each other. And our use of the major forms of communication that are available to us nearly always is dependent on our ability to pay (Roper 2013, p.235).

Technology, laws, bureaucracy and computerized electronic infrastructure and personal devices, fused together culminate in a global revolutionary electronic-interactive mode of production, in which dead labor inverts subject into object and humans confront their alienated labor in the form of computerized personal devices and infrastructure. This system of communication, data collection, surveillance, social media and commerce is termed perpetuum mobile based on Marx's idea about advanced social and production relations that hoards and circulates money continuously (Marx, 1973, p. 766; 1976,p. 227). The electronic results of this new mode of production are in a transition stage because telecommunication customers' unproductive work - their communications - are legally exploited or appropriated in the form of electronic data, which is subsumed or hoarded under capital, in a transitional or metamorphosing state, until deemed "productive," intangible, electronic commodity memory, with use, exchange and surplus value (Marx 1976 p. 990-991, 1044). As posited in "Results of the Immediate Process of Production," (Marx 1976; Mandel 1976, pp.943-947) labor objectives itself as a process of valorization that creates surplus value, validates how each epoch has within it the elements that will destroy and replace it. The growing published history of computer technology documenting the displacement of Machine Age modes of production, testifies to this dialectical historical argument (Bamford, 2009, 2012; Bush, 1945; Cortada, 2012; Greenwald, 2014; Haigh, 2010; O'Harrow, 2005; O'Regan; Packard, 2015; 2016).

Although scientists and other workers across the world incrementally crafted the electronic infrastructure for the dataveillance industry to collect, transmit and store electronic profiles of people's life activity, most people are not owners of these huge, sophisticated, data transmitting, processing, mining, collecting and storage companies. According to Oxfam's, "An economy for the 99 percent" (2017) only a handful of people draw their wealth from telecom related industries like: Microsoft (Bill Gates); Grupo Carso (Carlos Slim Helu); Aamozon.com (Jeff Bezos); Facebook (Mark Zuckerman); and Oracle (Larry Ellison). Adding to the profits, the Federal Communications Commission (FCC) legislation, signed on April 3, 2017, by President Trump, allows telecom companies to sell customer's browser histories (Leonard 2017). In December of 2017 the FCC voted to dismantle protective rules regulating how tech companies connect Internet users to the Internet, thereby allowing 
companies to determine and/or discriminate the experience of individual Internet users, with impunity (Kang, 2017).

Estrangement or alienation and dialectical materialism, which are what make Marx's approach to the study of capitalism unique, are the subject of a huge body of social science. For the purpose of this paper Marx's alienation theory is discussed using Marx's Economic and Philosophic Manuscripts of 1844 edited by R. Tucker (1978) and Marx's Theory of Alienation (1970) by I. Mészáros, which presents over 200 pages of careful analysis of the origin and structure of Marxian theory. Mészáros, examines alienation interpreted through: religion (man's separation from God); literature as "universal saleability" (the transformation of everything into a commodity); through historicity and the rise of anthropology and through the rise of "uncritical Postivism." Mészáros discusses how Marx's theory of alienation emerged from Hegel's (and other theorists) concept of "activity" as a division of labor and exchange activity of property, with the presupposition of property being private. Marx argued that political economists applied this concept of alienation to labor and exchange activity without including the "alienated" human labor manifest within the presupposed private property. Hegel's theoretical resolve for this dilemma, termed, "Aufebung" (two conflicting concepts are resolved by a third that transcends and preserves them), is unsatisfactory to Marx, because it is only "an abstract, imaginary negation of alienation as objectification” (Mészáros, 1970, p. 90). Marx's re-interpretation of this aufebung, claims alienation is objectification manifest in real tangible commodities and private property, rather than in imagined, mental activity or philosophy. Having acknowledged alienated human labor as manifest in material things (commodities, private property) the revolutionary question that Marx grapples with, might be stated this way: "How does the human transcend this alienation process and reunite this alienated part of him/herself with humanity, to enhance his/her "inner needs" and find fulfillment in his/her own activity and enjoyment in non-alienated products of his/her activity?" This question and Marx's theory of alienation, which turns Hegel's theory "on its head" is a revolutionary affront to capitalism because it recognizes human labor as real and material and a source of surplus value and suggests that people regain their full humanity by transcending the "alienated mediation" process of private property production and exchange.

Mészáros argues that education is one way for people to transcend alienated mediation, however it is in crisis because it is harnessed to corporate and war industry interests, which usurp educational resources for their own activity, at the expense of the students' development. Thus, progressive division of labor (progress) impoverishes education and the potential for people to transcend the alienation of the scientifically progressive commercialization, fragmentation and mechanical reification of the human activity (Mészáros, 1970, p. 299). The crisis of education, according to Mészáros is expressed as a contested debate about whether education should help men transcend alienation 
mediation or train them to serve the alienated social relations of corporate activity (p. 303) which in 1970, when Marx's Theory of Alienation was published, already included the burgeoning collaborative world-wide efforts of military, university and private corporations in developing the Internet, the pc and the World Wide Web, which would, by 2000, revolutionize both the means of production and the alienated mediation process, as Turkle and Foer describe.

For the purpose of this paper three alienated relationships are utilized: estrangement of worker from his objective man-made world; estrangement of the human from non-capitalist lifestyles, and the estrangement of man from himself. Estrangement from the objective man-made world is built on the presupposition that human labor reproduces itself both in its objectification and as labor commodity itself. The relationship of the worker to the product of his labor is one of alienation because the end product is outside of the human and it confronts him/her as alien and hostile (Marx, 1978 p. 72). Thus a private computer and the perpetuum mobile it is connected to, is the summation of decades of human labor, but it confronts the personal computer owner as an alien thing, (which might be why social media makes computers seem more familiar and less alien).

Another way of describing this is through the inverse relationship between the laborer and the objects produced by labor. The more labor invested in an object, the more valuable and intelligent the material object becomes and the more devalued and ignorant man becomes (which in the case of the perpetuum mobile is true, since the total apparatus holds and collects more knowledge and perhaps the codes to wealth, than the individual workers who assembled it). Marx argues the more civilized an object the worker creates, the more barbarous the worker becomes (Marx 1978, pp. 71-73); consider for example, the ingenious science of drone warfare in the hands of teenage or twenty year old postmillennium, gamers - or in the control of robots. In total, the objectified man made world, created by this capitalist progress, including the perpetuum mobile infrastructure, is alien and exercises power over the people who have created it. For example in, Pay any Price (2014) James Risen documents how Diane Roark, a staffer on the House Select Committee on Intelligence, assigned to handle oversight of the National Security Agency (NSA) uncovered the government cover-up of NSA spying, and asked NSA Director Hayden how long the program was going to run; he shook his head "no", and said, "It is among us" (Risen, 2014 pg. 250). This seems to indicate that this international electronic apparatus, that we depend on, or this perpetuum mobile, has power over its creators and is like an alien "among us."

Estrangement of the human from non-capitalist and non-exploitive lifestyles is necessary to assure reproduction of workers for capitalism and consumers for the workers' estranged products. In the capitalist mode of production people become estranged from the organic 
world, because unlike other animals, we appropriate far more from nature than what is necessary for survival; we do this because capitalist enterprises must always be expanding, exploiting more and more from natural resources and labor. A capitalist mode of production and lifestyle puts us at a survival disadvantage, since we have alienated ourselves from the option of a lifestyle that is less exploitive. A capitalist mode of production and lifestyle ultimately means that each person is estranged from the other, since this is necessary to perpetuate competitive capitalistic production and lifestyle. Or inversely, capitalism and profits decline in a context where there are united people, working for each other in less exploitive and sharing ways (Marx, 1978 pp.76-77). Marx describes what constitutes alienation of labor as the person's life energy becoming invested into the person's work, which becomes, or manifests ultimately as private property, which is the necessary consequence of alienated labor (1978, p. 79) and asks:

If the product of labour is alien to me, if it confronts me as an alien power, to whom then, does it belong? To a being other than me. Who is this being? . . . The alien being, to whom labour and the produce of labour belongs, in whose service is done and for whose benefit the produce of labour is provided, can only be man himself. . . . The medium through which estrangement takes place is itself practical (Marx, 1978 pp. 77-78).

The alienated products of labor are sold back to the human producers, through a medium that is "practical," like Amaozon.com. Presently Amazon's owner is one of the richest men in the world but the products Amazon sells are the alienated output of the workers, or their estranged labor, which the workers are now buying back as private property. This is contingent upon alienation, which Marx reveals here:

Alienated labour has resolved itself for us into two elements, which mutually condition one another, or which are different expressions of one and the same relationship. Appropriation appears as estrangement, as alienation; and alienation appears as appropriation, estrangement as true enfranchisement. (Marx 1978, p.81)

Essentially appropriation is in an exchange relationship with alienation manifest through the product of alienated labor, which is private property, which alienates human from human and human from nature. For example, the private property of the electronic infrastructure of the surveillance state embraces both the relationship of the worker to work (computerized work spaces) and the relationship of the worker to the non-worker (the personal cell phone). Both these relationships utilize the alienated private property electronic perpetuum mobile infrastructure for exchanging appropriation for estrangement and vice versa, in the course of the unceasing turnover of money by a global machine of 
indestructible materiality, circulating a repeating and alternating flow of sale and purchase. Marx ends the section on estranged labor by theorizing private property as the alienated manifestation of estranged labor encompassing the relationships of worker to work and to the alienated person's relations to the man-made world and to the non-worker (Marx, 1978 p.81)

\section{Literature Review}

The literature on the topic of cell phone and Internet abuse is awe-inspiring. Using the search terms "internet addiction" on Wiley Online Library Database on January 15, 2018, netted 9,851 article results, all within journals with titles like, Journal of Computer-Mediated Communication, Journal of School Health, The American Journal on Addictions and AsianPacific Psychiatry. A search of the Bio Med website showed 673 results for "internet addiction" and other research about the effect of internet and social media use on young peoples' brains and other aspects of Internet addiction (IA) which according to one commentary, is not yet officially codified within a psychopathological framework, but is growing both in prevalence and public consciousness (Christakis, 2010). Discussions about IA being included into the DSM-V are preempted by arguments that more scientific research is needed. There is academic research about student cell phone use in the classroom and cell phone use in relationship to school performance (Benjamin, 2016; Huang, 2014). There are studies about social media and narcissism (Buffardi and Campbell, 2008). There are volumes of self-reporting survey research that examines people's cellphone and social media use habits. Searches of social science journals turn up countless articles on the topic of Internet use and abuse.

While numerous studies offer self-reporting of PMPU, cautionary passages also appear in the articles. Researchers temper their findings with references to other studies that show self-reporting can often be inaccurate (Boase and Ling, 2013). Also, the disorders written about in these reports regarding extraversion, attachment style or fear of missing out (FOMO) point out a lack medical evidence regarding etiology. For example, Fear of Missing Out (FOMO), which is when people obsessively check phones because they fear missing out on an event, was made famous by Patrick J. McGinnis, an American venture capitalist and adviser to the World Bank. He introduced the idea of FOMO in a 2004 article in HARBUS, the student newspaper at Harvard Business School. Later a report in Communication \& New Media summed up the history of FOMO and suggested that it is a manufactured disease (Gaughan, 2015).

Joel Billieux, Associate Professor of Clinical Psychology, has a Citations Google Scholar link where dozens, maybe hundreds, of studies regarding on-line and cell phone related addictive behaviors, impulsivity and related experimental psychopathology are archived. 
One article titled, "Internet Addiction: A Systematic Review of Epidemiological Research for the Last Decade" is a literature review of a decade worth of empirical research about Internet addiction. The authors of this study concluded:

In sum, the present literature review of epidemiological empirical Internet addiction research has shown that there are problems in the assessment of Internet addiction. No clear gold standard exists based on which the status and severity of Internet addiction symptoms can be evaluated, and neither is the usage of . . . current tools standardized in such a way that cross-study comparisons are facilitated. In light of this, it is recommended that (i) a clearly defined nosology of Internet addiction is established as clear-cut psychopathological entity (Kuss, Griffiths, Karila and Billieux, 2014, pp. 21-22).

According to this study IA has yet to be scientifically substantiated before drug treatments can be applied; while at least one study reports a drug treatment program prescribed to someone with an internet porn habit (Bostwick and Bucci, 2008). Other studies focus online gaming, which has a Game Addiction Scale (Khazaal et al., 2016). While researchers debate if social media addiction is legitimate science, news coverage from diverse sources such as CBS, Huffington Post and Global Critical Media Literacy Project weigh in on the issue from the perspective of the general public, giving credit to researchers but also to people's own experiences, opinions and even the experiences of reporters (Augenbraun, 2014; Brewer, 2014; Feiler, 2014; Gregorie, 2014; Williams and Gaehde, 2017).

And there is brain research. An Italian study measured emotional states of Facebook users in 2011 and discovered that psychophysiological measures describe a core flow state while using Facebook, which is a psychophysiological state of high arousal and positive valence (Maurizio, M., Cipresso, P., Balgera, A., Villamira, M. and Riva, G., 2011). In the same year, a team of scientists in China found that grey matter volume in the brain diminished in relation to the extent adolescents spent time interacting with video games (Yuan et al., 2011). Marx's dialectal theory posits that the more labor a person invests into an object, the more intelligent the object becomes the more the human becomes an idiot (Marx, 1978 p.73). This is compounded when the game that is being played is actually learning from (in terms of artificial intelligence) the interacting human.

In 2013, an article titled, "Nucleus accumbens response to gains in reputation for the self relative to gains of others predicts social media use" reported that people's left nucleus accumbens is activated by "gains in reputation for the self" (Meshi, Morawetz and Heekeren, 2013). The left nucleus accumbens is at the lower left side of the brain near the spinal column and it is activated by rewards and positive gestures. Meshi et al. had an a priori hypothesis that they would find a relationship between Facebook use and neural 
processing of positive social feedback that validates ones reputation, based on an earlier experiment by Demos, Heatherton and Kelly (2012). The Meshi et al. (2013) results confirmed Facebook use is predicted when people's left nucleus accumbens is activated by positive social feedback from Facebook users. Meshi et al. validate the earlier study by Maurizio, Cipressio, Balgera, Villamira and Riva (2011) titled "Why is Facebook So Successful? Psychophysiological Measures Describe a Core Flow State While Using Facebook." which used P.J. Lang's Model of Emotions and the concept of being in flow, as posited by $M$. Csikszentmihalyi, as a methodological framework for measuring the emotional states of Facebook users. The conclusion to the earlier report states:

The study shows results that support the hypothesis that Facebook use is able to generate an experience marked by a specific psychophysiological pattern in comparison to relaxation and stress situations, correlating in particular with an affective state characterized by high positive valence and high arousal, leading to a core flow state that might represent a key actor able to explain why social networks are spreading out so successfully.

(Maurizio, Cipresso, Balgera, Villamira and Riva, 2011, p. 730)

Given these empirical brain science findings, what kind of research is there about the interactive effects of Internet and electronic device use on the body, for example the body's adrenal system? Here the word searches net very little in contrast to the searches noted above. Perhaps obtaining permission for human experimentation for such research is problematic. One study by R. Riedl titled, "On the Biology of the Technostress: Literature Review and Research Agenda" insists that "technostress" on the body has "hardly been addressed from a biological perspective" (Riedl, 2013, p. 19) and provides a literature review of empirical studies about human-computer interaction research regarding measuring the impact of computer usage on human bodily functions, along with a plan for further study of this "dark side" of computer use (2013, p. 19). Riedl synthesizes existing research on tests regarding computer usage on human biological systems (genetic, central nervous, autonomic and somatic nervous and endocrinological systems) while urging for more and better research that might make the computer less stressful and more accommodating to the health and safety of the humans who use it. Riedl ends his article stating:

If technology is the users' foe, corresponding stress perceptions can be objectively measured. However, making technology the users' friend must be a major goal of IS research. Whether or not a specific technology is userfriendly can also be investigated by means of biological approaches. This is an issue of real consequence, as signified by a recent study (Mauri et al., 2011) 
that uses biology to explain the success of Facebook, a technology that has recently reached one billion active users (www.facebook.com). Given the critical value of research into biology of human interaction with technology future studies can be expected to reveal rewarding insights

(Riedl, 2013, p. 47)

Reidl is addressing the Information Systems (IS) community and the literature he reviews is oriented towards the work environment, not towards the social media user. Nevertheless, the quote above might hint that engineering the work environment computer to be more user-friendly to the human (the way Facebook usage sends rewards to the brain) can make the technology less stressful and more "rewarding" to the worker in the workplace.

Other research examines gaming activity, illegal activity and also on-line recruitment of impressionable young people into terrorist activities. One article titled, "Cyber-Extremism: Isis and the Power of Social Media" by Imran Awan reports:

The findings in this study confirmed the author's original hypothesis, i.e. online hate is being used by groups such as Isis for a variety of reasons such as recruitment and propaganda. Moreover, this material is co-ordinated and controlled by Isis as a means for publishing and sending out key messages. (Awan, 2017, pg. 138)

At the end of the article the author writes: "From the collection of data analyzed it does appear that in some cases these individuals are seeking an adrenaline rush and are looking for excitement. This leads to different people with various aims and views" (Awan, 2017, p. 148). So there may be a biological "adrenaline rush" that users seek in cyber-extremist websites that is difficult to study scientifically (in terms of the body and an addictive interactive experience). But if there is an addictive drive behind using these websites (which is not really tied to wanting to engage in hate groups themselves) such activity could produce inaccurate meta-data regarding tracking of so-called terrorists by monitoring agencies mandated to hunt for terrorists in meta-data, because as Awan states, the users have different aims and views and may be seeking an adrenaline rush, more than involvement in a terrorist group.

There is much research regarding narcissism and social media use. Some of the research is trying to measure and understand how narcissists use Facebook to initiate relationships that constantly affirm their narcissistic esteem; a behavior linked to dispositional impulsivity. Researchers report that social media is a comfortable place for narcissists because the user has control over the presentation of their image and the context of the website, which is also conducive to shallow communication and temporary relationships with an emphasis 
on quantity, over quality of relationships (Buffardi and Campbell, 2008). Elliot Benjamin a retired psychology professor, reports that the personality psychology methods used to treat disorders like narcissism in the 1970s have been displaced with clinical and drug regimented treatments. He reports a significant increase in narcissistic behavior and habitual cell phone use among students in college classes (Benjamin, 2016). Narcissism is associated with an obsession with oneself and one's appearance or public persona. According to Wikipedia, Narcissus was the son of the Greek river god Cephissus and nymph Liriope. He was very beautiful but proud and distained those who loved him. Nemesis showed Narcissus his reflection in a pool and not realizing that it was only an image, Narcissus fell in love with it, lost his will to live and died staring at his reflection.

\section{Conclusion}

Addictions are costly to society. Today opiate addiction is the leading cause of death of U.S. citizens under age 50 (Katz 2017); at least eight states have declared statewide emergencies due to heroin and opioid addiction, overdose and public health problems (Couloumbis and Navratil 2018) Alcohol abuse is the fifth leading risk factor for premature death and disability according to the National Institute on Alcohol Abuse and Alcoholism (www.niaaa.nih.gov/alcohol-facts-and-statistics). Gambling addiction, made worse with online gambling, has necessitated the development of statewide networks of gambling courts in the U.S. to rehabilitate gambling addicts who steal to support gambling habits (Belson, 2007). These represent only three kinds of addictions that are generally associated with adults. It is notable that much of the research discussed above was conducted on young people using interactive devices and social media, which hasn't been around as long as opium or alcohol. But it makes one wonder what one single lifetime of narcissist habitual interaction with the perpetuum mobile will look like after the users age and no longer have young and beautiful images to post on Facebook. But, as yet, this seeming habitual interaction activity is still being studied. One study by Longstreet and Brooks asserts that social media addictions grow as our dependence on technology increases and that there is an inverse relationship with between life satisfaction and social media addiction. Essentially the study concludes that users use the internet as a surrogate for happiness, so when life satisfaction decreases, people use the internet to seek happiness, but if they become addicted to the social media (in search of happiness or to escape a unsatisfied life) than the addiction may cause stress and dysfunction, that in turn exacerbates the use of the social media, thus setting in motion a self-perpetuating cycle (Longstreet and Brooks, 2017). Such a cycle characterizes addiction behavior, where there is increased craving for something that is less and less satisfying.

Societies deal with addictions in different ways. The Chinese ridded their country of opium imposed on them by British "free trade," through sever social programs, after trying 
unsuccessfully to forcefully resist the British importers. Today President Duterte, of the Philippines, has death squads killing drug users (Lamb, 2017). A few years ago people smoked cigarettes inside almost any building in the U.S. When science and social movements joined forces with politics, smoking was banished from most U.S. public property, at about the same time that the cell phone arrived on the market. Perhaps it's too early to know if society will become attached to the perpetuum mobile in the same way that societies are attached to climate changing gasoline and automobiles; or perhaps it's too late. How can we detach from that which holds our lives together both economically and socially? And holds copies of our creations, knowledge, information, art, records and beloved social media, when all are threatened by destabilization from everything from corporate bank appropriation, to addictions, manufactured terrorist activity, depletion of the natural environment, to climate change and constant wars?

From a Marxian standpoint, the perpetuum mobile represents the historical material culmination of all of human labor and wisdom, manifest in material infrastructure, along with the private property devices that connect the individual to it. This perpetuum mobile is an un-human powerhouse of data collection and surveillance activity that collects and processes our electronic memory or data, imbuing it with exchange and use value for us and corporations and governments. Marx used the term perpetuum mobile to describe the unceasing turnover of money by a machine of indestructible materiality, circulating a repeating and alternating flow of sale and purchase (Marx 1973 p. 766; Marx 1976 p. 227). Essentially we build electronic data files with our electronic exchanges and communications via our private interactive/tracking objects, in the course of each day. Our commodity memory profiles are an intangible record of the life history of a person congealed in electronic memory product, an "x-ray of the soul" (Foer, 2017, p. 201) outside of us, like a commodity.

The perpetuum mobile is a machine that appropriates money, information and intelligence from the individual who exchanges these for alienation from other people, from nature and from the products of human labor. What work one does on the perpetuum mobile network is appropriable by others, what feelings or thoughts one shares on line is appropriable by others. To fill in the loss, and avoid FOMO one may shop on line at amazon and not even have to engage in shopping in a human populated store. The money is appropriated through the perpetuum mobile from the individual who exchanges his/her alienated labor, for that which was made by his/her fellow laborer, who is also alienated, while the profit is appropriated by one of the six richest men in the world. In "The Meaning of Human Requirements" Marx explains estrangement as the realization that everything in itself, is something different from itself, and this applies to the capitalist as well: 
Estrangement is manifest not only in the fact that my means of life belong to someone else, that my desire is the inaccessible possession of another, but also in the fact that everything is in itself something different from itself-that my activity is something else and that, finally (and this also applies to the capitalist), all is under the sway of inhuman power. There is a form of inactive, extravagant wealth given over wholly to pleasure, the enjoyer of which on the one hand behaves as a mere ephemeral individual frantically spending himself to no purpose, knows the slave-labour of others (human sweat and blood) as prey of his cupidity, and therefore knows man himself, and hence also his own self, as a sacrificed and empty being. With such wealth the contempt of man makes it appearance, partly as arrogance and as a squandering of what can give sustenance to a hundred human lives, and partly as the infamous illusion that his own unbridled extravagance and ceaseless, unproductive consumption is the condition of the other's labor and therefore his subsistence. He knows the realization of the essential powers of man only as the realization of his own excesses, his whims and capricious, bizarre notions. This wealth which, on the other hand, again knows wealth as a mere means, as something that is good for nothing, but to be annihilated and which is therefore at once slave and master, at once generous and mean, capricious, presumptuous, conceited, refined, cultured and witty- this wealth has not yet experienced wealth as an utterly alien power over itself; it sees in it, rather, only its own power, and not in wealth but gratification [is its] final aim and end. (Marx 1978, p. 100-101)

Applying Marx's analysis, above, to the perpetuum mobile, might be interpreted in the following way. Humans have created a perpetuum mobile that contains all their knowledge and work and life information outside of them. The humans use this perpetuum mobile for life needs and work, but also look into its' reflection seeking social unity to others who are only images, to escape from the feeling of emptiness and sacrifice - the feeling of missing what the perpetuum mobile shows as a reflection of appropriated human sociality. Being unable to obtain that alienated social unity we settle for gratification in capricious ways, such as buying a private rocket company; or use the mobile for labor, but either way, the more we spend ourselves in interaction with the perpetuum mobile, the more alienated we become from each other, from nature and our own work, because the perpetuum mobile appropriates from the user: money; time; life energy and knowledge. It becomes a greater alien power that exchanges peoples' estrangement, for appropriation, under the hypnotizing fantasy that users are connected there and being liked, as if in solidarity, when in fact they are exploited and appropriating from others there too; thus perpetuating the capitalist enterprise and their own alienation and pacification (Halper 2015) while depleting earth and nature of the resources our lives depend upon (Saito, 2017). 
In an "Ethics \& Law: A Feminist Perspective" class taught by Dr. Renata Saleca in 1995, the professor related to the class that a colleague of hers had observed that although the so-called War on Drugs had been waged for years, across the world, with abundant funding, drug use and drug dealing only continued to increase. The colleague attended lavish conferences and made many reports about drug abuse, but always drug use and dealing continued. It is almost as if by funding a network of experts to study the drug problem governments could absolve themselves of responsibility for resolving the social problems of drug addiction and organized crime, which continue to flourish, sometimes being fostered by authorities. Looking at the massive quantity of statistical and empirical studies regarding Internet and social media abuse, around the world, might make one wonder if the War on Drugs is being resurrected within a different kind of addiction and economic system. Among other things, addictions are social drivers of money turnover. Money turnover is expressed in at least two ways in this Marx inspired lens of analysis. First the money exchanged for a commodity represents alienated labor being purchased by the worker in the form of private property, like a cell phone. Second, the cell phone interaction manifests in intangible electronic memory or meta data, which is a captured byproduct in a transformative state; residue left behind after internet users engage in interactions wherein alienation is exchanged for appropriation - driven sometimes by addiction for rewards, a behavior perhaps similar to the behavior of Pavlov's dogs. This meta data captured in a transitional state may in time be ascribed use and exchange value that in turn becomes a commodity with surplus value, which may or may not be exchanged in a hidden, non-public or money laundering market place. In conclusion, it appears that Marx's theories about alienation, class struggle and dialectical materialism, apply in a new electronic perpetuum mobile mode of production era, characterized by intangible commodities, secret markets and unceasing hoarding and turn-over of money, partly driven by habitual or even addictive interactive exchange activity of paying customers, who may or may not be, wage laborers, who enrich a $1 \%$ capitalist class.

In 1970 Mészáros asked whether education is to help men transcend alienation mediation or to train them to serve the alienated social relations of corporate activity (p. 303). In 2017, Foer reported on the progress of some of those corporate social relationships in World Without Mind: The Existential Threat of Big Tech. One conclusion drawn from Foer's report on major actors in the tech companies, might be summed up this way: education for transcending alienation mediation isn't really needed any more than critical thinking is, because the companies have a solution to the limitations of the human mind. Thanks to the Law of Accelerating Returns, humanity is on the threshold of massive leaps in genetics, nanotechnology and robotics, which by 2045 , will allow us to shed our bodies and become virtual, with uploaded brains, making us software, not hardware and no different from robots or perhaps addicts under the sway of an inhuman power. This socially engineered solution will allow computers to relieve humans of the burden of thinking critically and having to be 
responsible for our actions and choices; freeing humans to live a life of leisure (Foer 2017 pp. 47-48). Mészáros wrote that an individual's self-realization is inseparable from the types and forms of social institutions in which the individual integrates him/herself into (1970, p. 253) which seems to mesh with Turkle's approach to the perpetuum mobile, particularly as posited to young people, in her Falling for Science: Objects in Mind (2008) book. Mészáros points out that Heidegger used the term "falling" to describe people being "thrown" into an alienated world (Mészáros 1970, p. 282). Could tech industries' socially engineered solutions to human limitations be a transcendence from alienation mediation and be the answer to the question, "How does the human transcend this alienation process and unite this alienated part of him/herself with humanity, to enhance his/her 'inner needs' and find fulfillment in his/her own activity and enjoyment in non-alienated products of his/her activity?" Who will debate such questions in the future? "Hive-minded" humans, robots or algorithms programed to supply an answer that produces the most likes? Will such questions be conceivable? How will people who are anxious and preoccupied with controlling their digital image, reckon with problems in the non-digital world? By following twitter orders? Will questions like these even be asked? If so, will the electronic media user's answer be contingent upon an anticipated "hit" or "fix", that keeps the user plugged in, giving up more and more of his/her attention and his/her information, providing more grist for lucrative government surveillance contracts (Foer, 2017, p. 188) or corporate plunder? Perhaps questions like these belong in the growing mountain of Internet user behavior survey questionnaires, for ordinary Internet users to think about and answer.

\section{Acknowledgments}

Thank you to Dr. Mike Lloyd of Victoria University of Wellington, Sociology Department, New Zealand for comments on this paper. Thank you to reference librarians Rohini Biradavolu and Sue D'Ath of the Kelburn Library of Victoria University of Wellington, for providing articles by I. Awan and R. Riedl. Thank you to the anonymous IJoSS reviewers for comments on the paper. Thank you to Dr. Robert Allison for reading drafts.

\section{References}

AUGENBRAUN, E. (2014, August 22). How Real a Risk is Social Media Addiction. CBS News. Available at: https://www.cbsnews.com/news/how-real-a-risk-is-social-media-addiction/ [17 January 2018]

AWAN, I. (2017, March 15). Cyber-Extremism: Isis and the Power of Social Media. Social Science and Public Policy. Available at DOI: 10.1007/s12115-017-0114-0. [17 January 2018].

BAMFORD, J. (2009). The shadow factory: The ultra-secret NSA from 9/11 to the Eavesdropping on America. New York, NY: Anchor Books. 
BAMFORD, J. (2012, March 15). The NSA is building the country's biggest spy center (watch what you say).Wired, 20(4). Available at: http://www.wired.com/threatlevel/2012/03/ff nsadatacenter/all/ [17 January 2018].

BELSON, K. (2007, May 1). Stressing Help, Not Penalties, In Gambling Treatment Court. New York Times, A1.

BENJAMIN, E. (2016). Humanistic Antidotes for Social Media/Cell Phone Addiction. In the College Psychology Classroom. Journal of Arts \& Humanities 5, (8): 1-11. Available at: http://www.theartsjournal.org/index.php/site/index

BOASE, J and LING, R. (2013). Measuring Mobile Phone Use: Self-Report Versus Log Data. Journal of Computer-Mediated Communication, 18 (4): 508-519. Available at: http://onlinelibrary.wiley.com [30 July 2017].

BOSTWICK, M.J \& BUCCI, J. (2008) Internet Sex Addiction Treated with Naltrexone. Mayo Clinic Proceedings, 83, 2, 226-230. Available at: DOI: 10.4065/83.2.226 [17 January 2018].

BREWER, J. (2014). Are We Addicted to Facebook, or Are We Just Addicted to Ourselves? Huffington Post. Available at: http://w.w.w.w.huffingtonpost.com/dr-judson-brewer/social-mediaaddiction b 4079697.html [25 June 2017]

BUFFARDI, L.E. and CAMPBELL, K. (2008). Narcissism and Social Networking Web Sites. Personality and Social Psychology Bulletin (PSPB), 34, 10, pp. 1303-1314. Available at DOI: 10. 1177/014616720832006. [17 January 2018].

BUSH, V. (1945, July 1). As We May Think. The Atlantic. Available at: hhtp://www.theatlantic.com/magazine/archive/1945/07/as-we-may-think/303881. [17 January 2018]

CHRISTAKIS, D. A. (2010). Internet addiction: a $21^{\text {st }}$ century epidemic. BMC Medicine, 8:61. Available at: https://bmcmedicine.biomedcentral.com/articles/10.1186/1741-7015-8-61 [17 January 2018]

CORTADA, J.W. (2012). The Digital Flood: The Diffusion of Information Technology. New York, N.Y.: Oxford University Press. Available at: DOI: 10.1093/acprof:oso/9780199921553.001.0001 [17 January 2018].

COULOUMBIS, A. and NAVRATIL, L. (2018, January 10) Gov. Wolf to declare opioid emergency in Pennsylvania. Pittsburgh Post-Gazette.

DEMOS, K. E., HEATHERTON, T.F. and KELLY, W. M. (2012). Individual differences in nucleus accumbens activity to food and sexual images predict weight gain and sexual behavior. Journal of Neuroscience. 32, 5549-5552. Available at: DOI: 10.1523/JNEUROSCI.5958-11. 2012 [17 January 2018].

DOSSEY, L. (2014). FOMO, Digital Dementia, and Our Dangerous Experiment. Explorations The Journal of Science and Heal. Available at: DOI:10.1016/j.explore.2013.12.008 [17 January 2018].

EGAN, M. and FIEGERMAN, S. (2017, July 27). Jeff Bezos briefly dethrones Bill Gates as world's richest person. Fear \& Greed Index, CNNTech.

EGGERS, D. (2013) The Circle. London: Penguin Books

ELLIOTT, L. (2017, January 16). World's eight richest people have the same wealth as poorest $50 \%$ : A new report by Oxfam warns of the growing and dangerous concentration of wealth. The Guardian. Available at:https://www.theguardian.com/global-development/2017/jan/16/worlds-eight-richest-people-havesame-wealth-as-poorest-50. [17 January 2018]

FEILER, B. (2014, May 11) For the love of Being "Liked". New York Times, ST2. 
Available at: https://www.nytimes.com/2014/05/11/fashion/for-some-social-media users-an-anxietyfrom-approval-seeking.html [17 January 2018].

FOER, F. (2017) World Without Mind: The Existential Threat of Big Tech. New York: Penguin Press.

GAUGHAN, D. (2015, April 29). FOMO: The Fear of Missing Out and how it is evolving in todays' digital age.

Communication \& New Media. Available at: https://medium.com/communication-new-media/fomoc2bc16b32379. [17 January 2018].

GREENWALD, G. (2014). No Place to Hide: Edward Snowden, the NSA, and the U.S. Surveillance State. New York: Metropolitan Books.

GREGORIE, C. (2014, December 13). Research Links Addictive Social Media Behavior with Substance Abuse. Huffington Post. Available at: https://www.huffingtonpost.com/2014/12/13/social-mediaaddiction n 6302814.html [17 January 2017].

HAIGH, T. (2010). Computing the American Way: Contextualizing the Early US Computer Industry. IEEE Annals of the History of Computing, 32 (2), 8-20. Available at: https://muse.jhu.edu/article/394123 [17 January 2018].

HALPER, J. (2015). War Against the People: Israel, The Palestinians and Global Pacification London, UK: Pluto Press.

HAYTHORNTHWAITE, C. and KENDELL, L. (2010). Introduction: Internet and Community. In C. Haythorthwaite \& L. Kendall (Eds). American Behavioral Scientist 53, 8, pp. 1083-1094. Available at: DOI: 10.1177/0002764209356242 [17 January 2018].

HORRIGAN, J. B. (2006). Portraits of American Internet Use. In R. Kraut, M. Brynin, and S. Kiesler (Eds.) Computers, Phones, and the Internet: Domesticating Information Technology. Available at: DOI:10.1093/acprof:oso/9780195312805.003.0002 [17 January 2018].

HUANG, G. (2014). Social Media Generation in Urban China: A Study of Social Media Use and Addiction Among Adolescents. Heidelberg: Springer. Available at: DOI: 10.1007/978-3-642-45441-7 [17 January 2018].

KANG, C. (2017, December 14). F.C.C. Repeals Net Neutrality Rules. New York Times.

KATZ, J. (2017, June 5). Drug Deaths in America Are Rising Faster Than Ever. New Data Compiled from hundreds of health agencies reveals the extent of the drug overdose epidemic last year. The New York Times. Available at: https://www.nytimes.com/interactive/2017/06/05/upshot/opiod-epidemic-drugoverdose-deaths-are-rising-faster-than-ever.html [17 January 2018].

KHAZAAL, Y., CHATTON, A., ROTHEN, S., ACHAB, S., THORENS, G., ZULLINO, D., and GMEL, G. (2016). Psychometric properties of the 7-item game addiction scale among French and German speaking adults. BMC Psychiatry. 16:132 Available at: https://doi.org/10.1186/s12888-016-0836-3

KUSS, D.J., GRIFFITHS M.D., KARILA, L., and BILLIEUX, J. (2014). Internet Addiction: A Systematic Review of Epidemiological Research for the Last Decade. Current Pharmaceutical Design, 20, 25, 1-27. Available at: https://www.ncbi.nlm.nih.gov/pubmed/24001297 [17 January 21018].

KUSS, D. (2015). Treating Internet Addiction-the Expert Perspective. European Psychiatry, 30,1. Available at: https://doi.org/10.1016/S0924-9338(15)30368-0 [17 January 2018].

LAMB, K. (2017, April 2) Thousands dead: the Philippine president, the death squad allegations and a brutal drugs war. The Guardian. Available at: https://www.theguardian.com/world/2017/apr/02/philippinespresident-duterte-drugs 
war-death-squads [17 January 2018]

LEONARD, S. (2017, April 6). You Are Now Paying Internet Companies to Sell Your Browsing History to Advertisers. The Nation. Available at: https://www.thenation.com/article/you-are now-paying-internetcompanies-to-sell-your-browsing-history-to-advertisers. [17 January 2018].

LIPMAN, J. (2013, March 14). Book Review: Sherry Turkle, Alone Together: Why We Expect More from Technology and Less from Each Other. Media Culture \& Society. Available at: doi/10.1177/0163443712472132f [17 January 2018].

LONGSTREET, P. and BROOKS, S. (2017). Life satisfaction: A key to managing internet \& social media addiction. Technology in Society 50, 73-77. Available at: http://dx.doi.org/10.1016/j.techsoc.2017.05.003. [17 January 2018].

LOPEZ-FERNANDEZ, O., KUSS D. J., ROMO, L., MORVAN Y., KERN L., GRANZIANI P., ROSSEAU A., RUMPF H.J., BISCHOF A., GÄSSLER, A.K., SCHIMMENTI A., PASSANISI A., MÄNNIKKO N., KÄÄRIÄNEN M., DEMETROVICS Z., KIRÁLY O., CHÓLIZ M., JOSÉ ZACARÉS J., SERRA E., GRIFFITHS M. D., PONTES H.M., LELONEK-KULETA B., CHWASZCZ J., ZULLINO D., ROCHAT L., ACHAB S. and BILLIEUX J. (2017). Self-reported dependence on mobile phones in young Adults: A European cross-cultural empirical survey. Journal of Behavioral Addictions, 6 (2), 168-177. Available at: DOI: 10.1556/2006.6.2017.020 [17 January 2018].

LOVERA, P. (2017, September 6). What does Amazon-Whole Foods Merger Mean for Consumers? Radio Interview by S. Kolhatkar. In Rising Up with Sonali. KPFA 94.1. FM, Berkeley, CA. Pacifica Radio. Available at: www.risingupwithsonali.com/?s=whole+foods [17 January 2018].

MANDEL, E. (1976). Introduction to Appendix. In Capital. Ed. Mandel, E. London, U.K: Penguin Books, pp. 943- 947.

MARX, K. (1973). Grundrisse: Foundations of the Critique of Political Economy. Trans. Nicolaus, M. New York: Vintage Books.

MARX, K. (1976) Capital: Volume I. Ed. Mandel, E. Trans. B. Fowkes. London, U.K.: Penguin Classics.

MARX, K., (1978). Economic and Philosophic Manuscripts of 1844. In The Marx -Engels Reader (2 ${ }^{\text {nd }}$ Ed) Ed. Tucker, R. New York: W.W. Norton \& Co. pp. 70-101.

MAURIZIO, M., CIPRESSO, P., BALGERA, A., VILLAMIRA, M., and RIVA, G. (2011) Why is Facebook so Successful? Psychophysiological Measures Describe a Core Flow State While Using Facebook. Cyberpsychology, Behavior and Social Networking, 14, (12) p.p. 723-731. Available at: DOI: 10.1089/cyber.2010.0377 [17 January 2018].

MESHI, D., MORAWETZ, C. and HEEKEREN, H.R. (2013) Nucleus accumbens response to gains in reputation for the self relative to gains for others predicts social media use. Frontiers in Human Neuroscience, 7, article 439. Available at: www.frontiersin.org, DOI: 10.3389/fnhum.2013.00439 [1 July 2017].

MÉSZÁROS, I. (1970). Marx's Theory of Alienation. London: Merlin Press.

O'HARROW, JR. R. (2005). No Place to Hide. New York: Free Press

O'REGAN, G. (2008). A Brief History of Computing. New York: Springer. https://doi.org/10.1007/978-184800-084-1 
PACKARD, N. (2015) Profiling the Machine Age into the Perpetuum Mobile. Innovative Journal of Business and Management, 4 (5), pp.104-113. Available at: DOI: http://dx.doi.org/10.15520/ijbm. vol4. iss5. 36. pp104-113 [17 January 2017].

PACKARD, N. (2016) Has the "Perpetuum Mobile" Age Arrived?" National Social Science Journal. 47 (1), pp. 84-92. Available at: nssa.us.org.

PACKARD, N. (2017) No Place to Hide, Before and After Data (Driven) Journalism. International Journal of Latest Research in Humanities and Social Science, 01, (2) pp. 24-36. Available at: www.ijlret.com.

RIEDL, R. (2013, February). On the biology of technostress: literature review and research agenda. Newsletter ACM SIGMAS Database: the Data Base for Advances in Information Systems, 44 (1). Available at DOI: 10.1145/2436239.2436242 [17 January 2018].

RISEN, J. (2014) Pay Any Price: Greed, Power, and Endless War. New York: Houghton Mifflin Harcourt.

ROPER, B. (2013). The History of Democracy: A Marxist Interpretation. London, U.K.: Pluto Press.

SAITO, K. (2017). Marx in the Anthropocene: Value, metabolic rift, and the non-cartesian dualism. Zeitschrift Fuer KritischeSozialtheorie Und Philosophie, 4 (1-2), 276-295. Available at: doi.org/10.1515/zksp2017-0013 [17 January 2018].

SANOU, B. (July, 2017). 2017 ITU ICT Facts and Figures. Available at: https://www.itu.int/en/ITUD/statistics/Documents/facts/ICTFactsFigures2017.pdf

SHKLOVSKI, I., KIESLER, S., KRAUT R. (2006). The Internet and Social Interaction. In Kraut, M. Brynin, and S. Kiesler (Eds.) Computers, Phones, and the Internet: Domesticating Information Technology. Available at DOI: 10.1093/acprof:oso/9780195312805.003.0017 [17 January 2018]

STATISTA: THE STATISTICAL PORTAL. (2017). Global digital population as of April 2017 (in millions). Available at: https://www.statista.com/statistics/617136/digital-population-worldwide/_[18 January 2018].

TURKLE, S. (2005) The Second Self: Computers and the Human Spirit, MIT Press, Cambridge, Mass. Available from: ProQuest Ebook Central. [12 January 2018].

TURKLE, S. (2008) Falling for Science: Objects in Mind, MIT Press, Cambridge. Available from: ProQuest Ebook Central. [12 January 2018].

TURKLE, S. (2011). Alone Together: Why We Expect More From Technology and Less From Each Other. New York, N.Y: Basic Books. Available at: ProQuest E Book Central. [12 January 2018].

WILLIAMS, R. and GAEHDE, M. (2017, April 17) Social Media Addiction: A Quick Look. Global Critical Media Literacy Project. Available at: http://gcml.org/social-media addiction-aquicklook/ [17 January 2018].

YUAN, K., QIN, W., WANG, G., ZENG F., ZHAO L., YANG X., YANG X., PENG, L., LIU, J., SUN, J., VON DENEEN, K. M., GONG, Q., LIU, Y., and TIAN, J. (2011) Microstructure Abnormalities in Adolescents with Internet Addiction Disorder. PLOSONE, 6 (6). Available at https://doi.org/10.1371/journal.pone.0020708 [17 January 2018]. 